\title{
AN INTEGRATED SCIENTOMETRIC AND SNA APPROACH TO EXPLORE THE CLASSICS IN CEM RESEARCH
}

\author{
Hengqin $W^{1}$, Zebin $Z H^{1}$, Xiaolong XUE ${ }^{1^{*}}$, Geoffrey Qiping $\mathrm{SHEN}^{2}$, \\ Rebecca Jing YANG ${ }^{3}$, Luqi WANG ${ }^{1}$ \\ ${ }^{1}$ School of Management, Harbin Institute of Technology, Harbin, China \\ ${ }^{2}$ Department of Build and Real Estate, The Hong Kong Polytechnic University, Hong Kong, China \\ ${ }^{3}$ School of Property, Construction and Project Management, RMIT University, Melbourne, Australia
}

Received 21 September 2019; accepted 18 December 2019

\begin{abstract}
This study explores the classics that significantly contribute to the research of construction engineering and management (CEM). Previous studies usually simply applied the number of citation to identify the classics, causing some flaws. To overcome the flaws, an advanced approach is developed by integrating scientometric methods (G-index and co-citation analysis) and a social network analysis (SNA) technique (modularity optimization algorithm), thus providing more precise and persuasive results that denote what academic works have made significant inspirations and illuminations on CEM research. This study retrieves 13,273 CEM literature and extracts 336,129 bibliographies from these literature. Based on the G-index, a total of 67 publications are identified as CEM classics. Moreover, this paper measures and maps the structure of the classics by using co-citation analysis and modularity optimization algorithm. The results provide a basic source of academic information representing the foundation of CEM and draw a big picture of CEM to show the underlying associations between the identified classics. This can help researchers recognize the key scientific contributions for improving the academy progress.
\end{abstract}

Keywords: classics, construction engineering and management, G-index, co-citation analysis, social network analysis, modularity optimization.

\section{Introduction}

Classics, defined as academic achievements that are generally recognized by the majority of academic scholars, are supposed to be necessary for an academic field to improve itself (Kuhn, 1962). According to Kuhn's book titled "The structure of scientific revolutions", when recognized as the classics by most of the experts, the academic works actually serve functions such as illuminations and examples including laws, theories, applications and instrumentations to progress and consolidate the scientific field itself (Kuhn, 1962).

After the beginning of the 20th century, the conventional "classics", like Ptolemy's Almagest, Opticks, and Aristotle's Physica, hardly emerged. Correspondingly, the practice of "citation classics" originated in the late 1970s and referred to such academic achievements that had been highly cited in their fields (Garfield, 1977). Classics are viewed as the "gold bullion of science" (Smith, 2007; Stack, 2012), which provide a basic source of academic informa- tion (Brandt et al., 2010) and represent the foundation and intellectual roots of a field and help researchers recognize the key scientific contributions to boost the academy development and progress (Aksnes \& Sivertsen, 2004; Cano \& Lind, 1991).

This paper investigates the academic field of construction engineering and management (CEM). The landscape of the world has been significantly transformed by physical and built environments - buildings and infrastructures, supporting spaces and places in which people live with less effort and more convenience (Gellert \& Lynch, 2003; Kennedy, 2015). Our build environment is developed by complex undertakings of construction and engineering processes, mainly delivered as projects with visible products including roads, tunnels, bridges, airports, railroads, facilities, buildings, dams, and utilities (Floricel et al., 2016). Due to their significant impacts on society, environment and economy, managers of projects have a

${ }^{*}$ Corresponding author. E-mail: xlxue@hit.edu.cn 
heavy responsibility for the construction projects, not only in a manner that maximizes value and minimizes risks with less time, but also reaching the goal of sustainable development (Flyvbjerg, 2014; Laurance et al., 2014). To meet the requirements from the managemental practice, CEM emerged and developed into a mature field that is essential to provide basic knowledge and to serve the educational purposes (D’Agostino, 2017; Levitt, 2007). After World War II, fundamental research of CEM mainly concerned the topics of planning, designing, construction, and management of buildings and infrastructures (Levitt, 2007), involving a number of researchers from academic communities.

Similar to other engineering disciplines, CEM absorbs and applies knowledge from physics, chemistry, management science, computer science, etc. as the underlying sciences to analyze and optimize the design and construction processes (Levitt, 2007). Thus, CEM is differentiated from management science because it requires the application of engineering principles and skills in organizing and directing people in a complex environment (Morse \& Babcock, 2010). These early CEM studies established theoretical foundations, developed tools, provided practical evidence in a localized environment, and improved the academic works through peer and practitioners review processes. In turn, these foundations, tools, and evidence contributed to the developments of thought, beliefs and methodologies in different parts of CEM, such as construction project management, modeling and optimization, construction design and control, building information modeling and so on (Levitt, 2007; Li et al., 2017). This triggers the discussions and concerns about the following questions: Among the plenty of CEM early studies, what academic works had become the classics to guide the research and practice of the different subareas of CEM? How do these classics interrelate with each other?

In order to provide insights into the above questions, this study aims to explore and analyze the classics in CEM by using a comprehensive approach which can provide more precise and robust results. In the field of CEM, several attempts have been made to identify the classics, but they only focus on the subfields (Flyvbjerg \& Turner, 2018; Li et al., 2017; Siemiatycki, 2016). The findings in this study can help the scholars to better understand which academic achievements significantly contribute to the CEM research. This study also provides a rational basis for practitioners to refer to, when retrieving and applying the important theories in the CEM area more effectively.

Most of the existing research identified the classics from journal papers, but high-impact publications always appear in references, not the papers (Seglen, 1998; Wu et al., 2020). In addition, the classics were always identified by using an arbitrary value of citation(e.g., top 50 or 100 cited papers) rather than a systemic index (Ho, 2014; Ibrahim et al., 2012; Korevaar \& Moed, 1996; Li et al., 2017; Powell, 2016). In the CEM area, previous studies have made some efforts to analyze the classics, but most of them failed to provide robust and convinced outputs as they do not overcome the limitations of conventional citation analysis mentioned above (Flyvbjerg \& Turner, 2018; Li et al., 2017; Siemiatycki, 2016). Moreover, such expositions may be unsatisfactory as they merely focused on how the identified classics affect the CEM development, but failed to draw a big picture for CEM that uncovers the underlying associations between different CEM's subareas.

The present study, not merely by applying the citation analysis, but by proposing a new comprehensive approach integrating scientometric methods (G-index and co-citation analysis) and a SNA technique (modularity optimization algorithm) to overcome the significant limitations of citation analysis, explores an advanced approach to identify the classics of CEM, reducing arbitrary and personal bias that always occurred in previous studies and providing precise and robust results. The results can help the academia understand the evolutionary history and the merits of those contributions held to be "classics" in the research field.

\section{Literature review}

The widely-accepted method used to explore and identify classics is citation analysis, whose results are typically called citation classics. The citation of an academic achievement refers to the times it appears in the reference lists of the succeeding publications, which is viewed as a straightforward way to assess the achievements in its academic area (Baltussen \& Kindler, 2004). Although some scholars hold debates for using the citation as a metric because: 1) the motivation of the citing behavior and the ways to count the citation number may be different, and 2) it does not differentiate the positive and negative credits, it represents a fundamental unit of measurement for assessing scientific performance (Ajiferuke et al., 2010; Brandt et al., 2010; Buschman \& Michalek, 2013). Therefore, the socalled "citation classic" papers (Garfield, 1976; Kelly et al., 2010), which are also called highly-cited articles (Aksnes, 2003), top publications (Korevaar \& Moed, 1996), classic articles (Long et al., 2014) or classic literatures (Chinn, 2015), have been studied in various academic fields, such as medicine (Kelly et al., 2010), chemical engineering (Ho, 2012), information science (Leydesdorff et al., 2014), knowledge management (Serenko \& Dumay, 2015), and education (McLeskey, 2004). However, such methods have rarely applied in the field of CEM to identify and evaluate classical theories, articles or people.

Most previous studies identified the citation classics by setting a threshold value to filter highly-cited papers, such as fixing a minimum number (e.g., 100 or 50) of citations received (Ho, 2014; Ibrahim et al., 2012; Li et al., 2017; Powell, 2016), or a percentage (e.g., the top 0.5 percent highly cited publications) or a number of highly-cited publications (Aminian et al., 2015; Huang et al., 2015; Leydesdorff et al., 2014; Lo et al., 2016; Serenko \& Dumay, 2015). In addition, the $\mathrm{H}$-index has been used to objectively offer an unbiased criterion to filter classics (Martinez et al., 2015). H-index is one of the most frequently 
used scientometric indicators, reflecting the number of a scholar's most cited publications and the number of the citation that the scholar received (Hirsch, 2007). Compared with traditional methods, $\mathrm{H}$-index is regarded as a relatively unbiased approach to assess the scientific performance (Costas \& Bordons, 2008; Hirsch, 2005, 2007), but it fails to consider the highly-cited publications and scale-free nature of the distribution of references-citation system (Woeginger, 2008). Another indicator, G-index, in turn, was proposed as an advancement to overcome the drawbacks of $\mathrm{H}$-index, being recognized as an ideal measure of academic productivity (Egghe, 2006). However, regardless of the advantages, the G-index has not been used in identifying the classics.

Although citation analysis is controversial to some degree, given the current stage of academic development of the knowledge base, it represents a basic form of recognition. The main limitations of the previous methods used in the studies of "citation classics" are as follows.

(1) In most studies, journal papers are always the only source items of databases.

The "citation classics" are always identified from the retrieved papers in the databases. Therefore only journal papers could be identified as classics, whereas books and reports are excluded from being classics, regardless of their significant role in many research fields. In addition, publications from other fields that might have considerable impacts on the research of the given academic field are not always included as source items in previous studies.

(2) The criteria applied to identify classics is arbitrary to some extent.

It is still not convincing, as to the reasons why we must set a threshold value of 100 or 50 on the citation received to identify the classics, or to use the top 0.5 percent. Indeed, every academic field should have a unique number of classics, as each field has a unique development process and citation pattern. Although the $\mathrm{H}$-index does provide an objective criterion for identifying classics, it does not take into account the most highly-cited publications of an academic field (Woeginger, 2008).

\section{Methodology}

The proposed approach integrates scientometric and SNA methods. Scientometrics is the study of measuring and analyzing science, technology, and innovation (Lowry et al., 2004). The current study applies two scientometric methods: G-index and co-citation analysis. In addition, an SNA technique, modularity optimization is also embodied in this study. The authors retrieved the academic papers relevant to CEM and extracted all the references cited in those papers. The authors selected 13 prestigious journals in the field of CEM as the data source based on two criteria. First, the journals need to have significant impacts and unanimous recognition in the research community of CEM (Li et al., 2017; Lin \& Shen, 2007; Lu et al., 2015;
Olawumi et al., 2017; Wing, 1997). For example, Wing (1997) proposed the top CEM journals with highest scores in quality rating, including JCEM, JCEM-ASCE, ECAM, JME, IJPM, AIC and BRI (Table 1 shows the initials of the journals). Levitt (2007) reported that after the 1980s, computing approached became popular and many research came out in computer-aided journals, like CCE; Li et al. (2017) state that PMJ, IJPM and JME are renowned journals of CEM. Lu et al. (2015) selected JCEM-ASCE, ECAM, JME, IJPM, AIC, CCE and CCIE to conduct their work. Olawumi et al. (2017) found that most BIM research were published in AIC, CCE, CCIE, AEI, JCEM, and JME. Second, the journals need to be included in the Web of Science (WoS) or Scopus databases which are recognized as authoritative (Meho \& Yang, 2007). In addition, for the journals of WoS, they have to rank in the top 75\% (Q1, Q2 and Q3 in Journal Citation Report) in each of their subject categories. Following these criteria, 13 journals were selected, as shown in Table 1.

Based on the retrieved papers and references, the authors count the local citation count (LCC) of each reference (the occurrence times of each reference in the CEM papers), and G-index is used to filter the widely recognized academic research according to the LCC (Figure 1 illustrates the analysis procedure). Then the co-citation analysis and SNA are conducted to explore the relations between the classics of CEM. This paper describes the methodologies as follows.

\subsection{Data collection}

Overall, 11 out of the selected 13 journals of CEM were retrieved from WoS. The authors keep the important papers, by selecting the document types of "ARTICLE", "REVIEW", "EDITORIAL MATERIAL", "PROCEEDINGS PAPER" and "LETTER", since they are regarded as important documents types in WoS (van Leeuwen et al., 2013; Waltman, 2016). In addition, different document types have minimal impacts on the size-independent indicators such as H-index and G-index (Waltman, 2016). The papers of the other two journals were searched from the Scopus database, but only "ARTICLE" and "REVIEW" were searched because of the restriction of the database. The retrieval strategy is: "Publication name" = the 13 CEM journals' names. The authors retrieved all the CEM core journals' articles that are available by using the access of the authors' institute(s), and the time span is from 1985 to 2014. As Table 1 shown, four of the CEM core journals started their publications in 1983. Although this may cause the absence of some papers, the impact on the results is minimal. On the one hand, the number of papers not included in our database is rare (only two years are missed in four journals) compared with the papers retrieved from the database, which may have little influence on the data source. On the other hand, the publications that emerged before 1985 may be included as the source data for identifying the classics, because the authors do not explore the classics from papers but the references. 
Table 1.13 core journals of CEM

\begin{tabular}{|c|c|c|c|c|c|}
\hline No. & Journal & Source & 2018 IF & Quartile rankings in categories & Start Year \\
\hline 1 & Advanced Engineering Informatics (AEI) & WoS & 3.772 & $\begin{array}{l}\text { Q1 (Computer science, artificial intelligence) } \\
\text { Q1 (Engineering, Multidisciplinary) }\end{array}$ & 2002 \\
\hline 2 & Automation in Construction (AIC) & WoS & 4.313 & $\begin{array}{l}\text { Q1 (Construction \& building Technology) } \\
\text { Q1 (Engineering, Civil) }\end{array}$ & 1992 \\
\hline 3 & $\begin{array}{l}\text { Computer-Aided Civil and Infrastructure } \\
\text { Engineering (CCIE) }\end{array}$ & WoS & 6.208 & $\begin{array}{l}\text { Q1 (Transportation science \& technology) } \\
\text { Q1 (Computer science, interdisciplinary } \\
\quad \text { application) } \\
\text { Q1 (Construction \& building Technology) } \\
\text { Q1 (Engineering, Civil) }\end{array}$ & 1986 \\
\hline 4 & $\begin{array}{l}\text { Journal of Computing in Civil Engineering } \\
\text { (CCE) }\end{array}$ & WoS & 2.554 & $\begin{array}{l}\text { Q2 (Computer science, interdisciplinary } \\
\text { application) } \\
\text { Q2 (Engineering, Civil) }\end{array}$ & 1988 \\
\hline 5 & $\begin{array}{l}\text { International Journal of Project Management } \\
\text { (IJPM) }\end{array}$ & WoS & 4.694 & Q1 (Management) & 1983 \\
\hline 6 & Project Management Journal (PMJ) & WoS & 2.043 & Q2 (Management) & 2007 \\
\hline 7 & Building Research and Information (BRI) & WoS & 3.744 & Q1 (Construction \& building Technology) & 1991 \\
\hline 8 & $\begin{array}{l}\text { Construction Management and Economics } \\
(\mathrm{CME})\end{array}$ & Scopus & l & & 1983 \\
\hline 9 & $\begin{array}{l}\text { Engineering, Construction and Architectural } \\
\text { Management (ECAM) }\end{array}$ & Scopus & 1.561 & $\begin{array}{l}\text { Q3 (Engineering, Civil) } \\
\text { Q3 (Engineering, industrial) }\end{array}$ & 1994 \\
\hline 10 & $\begin{array}{l}\text { Journal of Civil Engineering and } \\
\text { Management (JCEM) }\end{array}$ & WoS & 2.029 & Q2 (Engineering, Civil) & 2002 \\
\hline 11 & $\begin{array}{l}\text { Journal of Construction Engineering and } \\
\text { Management (JCEM-ASCE) }\end{array}$ & WoS & 2.734 & $\begin{array}{l}\text { Q1 (Construction Building technology) } \\
\text { Q1 (Engineering, Civil) } \\
\text { Q2 (Engineering, industrial) }\end{array}$ & 1983 \\
\hline 12 & $\begin{array}{l}\text { Journal of Management in Engineering } \\
\text { (JME) }\end{array}$ & WoS & 3.269 & $\begin{array}{l}\text { Q1 (Engineering, Civil); Q2 (Engineering, } \\
\text { industrial) }\end{array}$ & 1983 \\
\hline 13 & $\begin{array}{l}\text { Journal of Professional Issues in Engineering } \\
\text { Education and Practice (PIEEP) }\end{array}$ & WoS & 1.372 & $\begin{array}{l}\text { Q3 (Education, Scientific Disciplines) } \\
\text { Q3 (Engineering, multidisciplinary) }\end{array}$ & 1985 \\
\hline
\end{tabular}

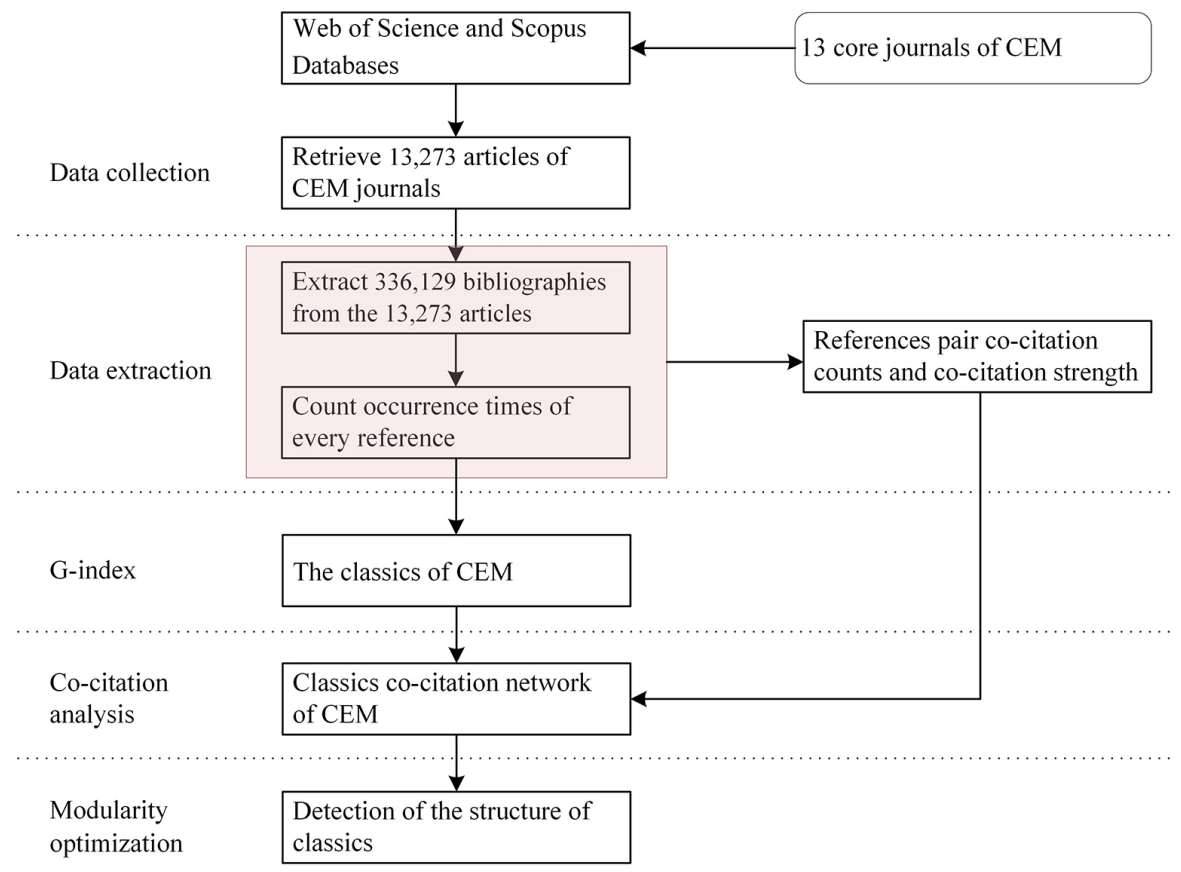

Figure 1. The procedure for exploring classics of CEM 
In total, 13,273 CEM papers and 336,129 bibliographies cited by these CEM papers were retrieved as the source database for further analysis. On average, each paper of CEM cited 25.32 references. Table 2 shows the number of documents and bibliographies for each document type.

Table 2. Number papers and bibliographies for each document type

\begin{tabular}{|l|c|c|c|c|}
\hline $\begin{array}{c}\text { Document } \\
\text { type }\end{array}$ & $\begin{array}{c}\text { Number } \\
\text { of papers }\end{array}$ & Percentage & $\begin{array}{c}\text { Number } \\
\text { of Bibliog- } \\
\text { raphies }\end{array}$ & Percentage \\
\hline Article & 11293 & $85.08 \%$ & 318166 & $94.66 \%$ \\
\hline $\begin{array}{l}\text { Editorial } \\
\text { Material }\end{array}$ & 1527 & $11.50 \%$ & 3272 & $0.97 \%$ \\
\hline $\begin{array}{l}\text { Proceedings } \\
\text { Paper }\end{array}$ & 355 & $2.67 \%$ & 7986 & $2.38 \%$ \\
\hline Review & 82 & $0.62 \%$ & 6669 & $1.98 \%$ \\
\hline Letter & 16 & $0.12 \%$ & 36 & $0.01 \%$ \\
\hline Total & 13273 & $100.00 \%$ & 336129 & $100.00 \%$ \\
\hline
\end{tabular}

\subsection{Data collection}

The G-index was introduced by Leo Egghe in 2006 to remedy some weaknesses of the popular H-index (Hirsch, 2005). Specifically, the G-index is the largest number that the top $\mathrm{g}$ articles cited $g^{2}$ citations together (Egghe, 2006). It is formally defined as follows:

$$
g^{2} \leq \sum_{i \leq g} c_{i}
$$

The G-index was initially designed to capture the overall performance of any information production process (IPP) (Egghe, 2005b). In the general meaning, any social system can be viewed as an IPP which has sources and corresponding items, such as authors (sources) $\rightarrow$ papers (items), articles $\rightarrow$ citations, references $\rightarrow$ citing times, words $\rightarrow$ occurrence times in a text, web sites $\rightarrow$ hyperlinks and so on (Egghe, 2009). In this study, the references of the CEM papers are considered as a part of such an IPP (references of the CEM papers $\rightarrow$ the times they are cited by the CEM papers). All the scientific productivity of IPPs obey the Lotka's law, because any social activity, including research works, is based on the principle "success-breedssuccess" (De Solla Price, 1976; Simon, 1955). So one publication that has been frequently cited is more likely to be cited again than the one that has been less cited. Therefore, for the references of CEM papers, the size-frequency relation between the reference and citation times align with the Lotka's law:

$$
f(i)=\frac{C}{i^{\alpha}},(C>0, \alpha>1) .
$$

According to the axiom above, the relation of $\mathrm{g}$ with the total number of sources (= references here) is given as follows:

$$
g=\left(\frac{\alpha-1}{\alpha-2}\right)^{\frac{\alpha-1}{\alpha}} T^{\frac{1}{\alpha}},(C>0, \alpha>1),
$$

where $T$ is the total number of references, $\alpha$ denotes the degree of scale nature of the system. From Eqn (3), the relation between G-index and $\alpha$ is well described, and $g$ will increase with the degree of the centration, or inequality of the citing times over the references. This relation can also be explained using the Lorenz curve. Through replacing persons with publications and income with received citations, the Lorenz curve (Lorenz, 1905) can be drawn to measure the inequality over references (Egghe, 2005a). It is proved that if the Lorenz curve $i$ of $X_{i}$ is above the Lorenz curve $j$ of $Y_{j}$, then the G-index $g(i)$ of $X_{i}$ is more than or equal to the G-index $g(j)$ of $Y_{j}$.

In general, G-index is better than H-index, which is considered as an ideal measure of academic productivity, because the G-index is sensitive to the highly-cited publications and the scale-free nature of the distribution of references-citation system (Woeginger, 2008). Moreover, any research area has a different $g$ which depicts the pattern of each research area. More than showing the size of the classics, the G-index also measures the impact of the core, which is not shared by other impact measures, such as the H-index (Chong et al., 2015).

\subsection{Co-citation analysis}

As a citation-based approach, co-citation analysis aims to explore the leading publications, journals, and scholars that are referenced by the citing academic sources. The fundamental assumption is that the co-citation network performs the essential features and structure of the intellectual base (Chen, 2004). A closer relationship between two publications is established when they are more frequently cited together (McCain, 1990; Ramos-Rodriguez \& Ruiz-Navarro, 2004; Small, 1973). Co-citation analysis has been applied to many fields, such as organization studies (Gmur, 2003), human resources management (Fernandez-Alles \& Ramos-Rodríguez, 2009), international management (Acedo \& Casillas, 2005) and supply chain management (Charvet et al., 2008).

In the document co-citation network, the nodes are the references cited by the publications included in the analysis. This study adopt cosine coefficients to compute the weights of links of the document co-citation network, which was as (Chen, 2004):

$$
c c[i, j]=\frac{c c[i, j]}{\sqrt{c[i] c[j]}},
$$

where $c c[i, j]$ is the co-cited counts of $i$ and $j$, denoting the times that $i$ and $j$ were simultaneously cited by the same literature. $c[i]$ and $c[j]$ are total citation counts. The cosine coefficients is similar to fractional counting that is proposed by Perianes-Rodriguez et al. (2016). Both methods aim to provide a more objective and comparable measurement of the co-cited units than traditional full counting, making weights of a co-citation link between 0 and 1 . This study adopted cosine coefficients because, for constructing the document co-citation analysis, it considers the impacts of all the citing publications, whereas fractional counting 
focuses on the publications that create the co-citation action - citing more than two references in the analysis (as for the details of cosine coefficients and fractional counting, please see Chen (2004) and Perianes-Rodriguez et al. (2016), respectively).

\subsection{Modularity optimization}

After constructing the co-citation network of CEM classics, we use an SNA technique - modularity optimization to systematically analyze the structure. SNA techniques were frequently adopted to measure the structure of cocitation networks, visually reflecting the intellectual structure of an academic area by conducting advanced algorithms and topological calculations (Pilkington, 2008).

SNA techniques can also reveal the high impact units in a network (Wasserman \& Faust, 1994) by examining the relational traits of social structures (Scott, 2012). Modularity optimization is an advanced social network technique to detect communities (Newman, 2006). It is defined as (Newman, 2004):

$$
Q=\frac{1}{2 m} \sum_{i, j}\left[A_{i j}-\frac{k_{i} k_{j}}{2 m}\right] \delta\left(c_{i}, c_{j}\right) .
$$

With modularity optimization, a network's structure can be identified by dividing the network into several communities based on the nodal linkages. Internal nodes in a community have many more connections than the external ones. Thus, the references in the same community tend to share similar topics, methods, or ideas (Small, 1973). In this study, modularity optimization is applied to identify the structure of the co-citation network in which the measured CEM classics are the nodes. In the co-citation network, a link and its weight denote the similarity of the two linked classics. By looking at the co-citation relationship, tightly-knit groups of CEM classics can be identified.

In summary, the advantages of the approach this study developed are as follows.

(1) Because the authors explore the classics of CEM from the references of journal papers but not the journal papers themselves, we identify what academic works have significantly impacted and illuminated those studies of CEM, rather than what papers of CEM have been highly cited. This means the approach would provide results that are closer to the characteristics of classics from the perspective of philosophy of science: Classics should guide and illuminate subsequent research and practice in the academic field.

(2) The source items are not limited to journal papers. As mentioned above, the present study identifies the classics from the references. This makes the journal article is no longer the only type of source items for classics. Other publication types such as books and reports that played prominent roles may be included as source items.
(3) The citation number is more reliable. Based on counting the occurrence frequencies of those references, the base criteria for classics is the citing times by the top CEM journal papers, not the citation provided by online databases (i.e., WoS or Scopus). In addition, rather than a concrete number or a percentage, the G-index was employed as a threshold to avoid bias of personal judgment and to make the procedure of identifying the classics more robust and persuasive.

\section{Results}

\subsection{The classics of CEM}

As mentioned in the data collection section, a total of 336,129 bibliographies are extracted from the CEM papers. The authors rank the references according to the times they occurred in the bibliographies (LCC) instead of the citation number in online databases (Global citation count, GCC) such as Google Scholar or WoS. Based on the LCC of the bibliographies and their rankings, the G-index of the cited references is calculated using $g=67$. This means the 67 most popular references of 336,129 bibliographies have been totally cited no less than $67^{2}=4489$ $(4551>4489)$ times by those documents of CEM journals. The 67 publications cited the most are identified as classics of CEM. A supplemental data file delivers more details about the 67 classics, including information on authors, titles, publication sources and years of publication. Regardless of the detailed information, some intriguing observations of the identified classics should be highlighted. (1) Overall, the most striking finding to emerge from the results is the 67 identified classics of CEM. The number is not set by personal judgment but G-index. Compared to a concrete number or a percentage such as top 100,50 or 10 the citations they received or top 0.5 percent highly cited publications (Ho, 2014; Ibrahim et al., 2012; Li et al., 2017; Powell, 2016), G-index can reveal the concentration of publication citations within a defined paper pool, taking the scale-free nature of the distribution of references-citation system into consideration (Woeginger, 2008). Moreover, each academic system should have a different value of G-index, and the number of classics in the different academic field should vary, rather than a concrete number.

(2) Several classic theories and methods from other academic fields are identified as CEM classics, such as "Case study research: design and methods" (Yin, 1994), "Analytic Hierarchy Process" (Satty, 1980), "Qualitative data analysis: A sourcebook of new methods" (Huberman \& Miles, 1994) and so on. As mentioned above, according to the definition, the classics serve to guide and illuminate the following research, and thus might not be limited to the investigated field. Moreover, CEM is widely accepted as an inter-disciplinary field, absorbing and adopting knowledge from other disciplines that may potentially provide classic theories or tools for CEM. Research to date has tended to retrieved academic publications by searching relevant keywords 
through online databases (Google Scholar and Web of Science) (Li et al., 2017), and set a threshold value by the citation numbers to identify classics. As a result, some publications are not included as source items for classics due to the search strategy, despite their prominent roles in the investigated academic field. Unlike the previous studies, this study identifies classics that are concentrated but not limited to the CEM papers, because the authors identify the classics within the references extracted from the CEM papers. Therefore, this study, in turn, identifies the significant publications from a broader scope that illuminated and impacted on the research of CEM, which is closer to the characteristics of classics from the perspective of philosophy of science.

(3) Besides the 45 journal articles, 20 books and 2 reports are identified as classics of CEM (Table 3). Many studies failed to identify books and reports as classics (Ho, 2014), despite their prominent roles in the research progress.

\subsection{Clustering the classics by co-citation analysis and modularity optimization}

The authors build up the co-citation network of by those classics and their co-cited relations. The overview of the co-citation network of CEM is presented in Figure 2.

As shown in Figure 2, the nodes are the 67 classics of the CEM, while the links between them denote their cocitation relationships. The size of each node denotes the times they have been cited by the CEM papers, whereas the thickness of links denotes the co-citation strength of the two nodes. The modularity optimization algorithm divides the CEM classics into different groups which can be distinguished by the attached colors.

There are 311 co-citation relationships between 67 references. As shown in Table 4, the average degree is 9.701, which means every publication has 9.701 co-citation links with others, on average. The density is 0.147 , which is much higher than many other social networks (Newman, 2004). The higher density indicates a better overall association of the CEM classics.

The authors name each of the split classic group based on manual review of the classics. At least the titles, abstracts and keywords were carefully read. Furthermore, to discern some ambiguous content, we have read the main body of the classics. The details of each group are shown in the following subsections.

\subsubsection{Group 1: Project management}

The resulting classics include 25 publications in this group, with 8 books and 17 journal papers (Table 5). The majority of the classics are about management issues of projects, such as project success (Cooke-Davies, 2002; Pinto \& Slevin, 1988; Shenhar et al., 2001), cost (Flyvbjerg et al., 2002), project organization (Hobday, 2000; Lundin \& Söderholm, 1995; Turner \& Müller, 2003) and so on. Moreover, from Table 5, the authors can observe that some theories and methods in social science are recognized as
Table 3. Distribution of classics of CEM by publication source

\begin{tabular}{|l|c|}
\hline \multicolumn{1}{|c|}{ Publication source } & Count \\
\hline \multicolumn{1}{|c|}{ BOOKS } & 20 \\
\hline $\begin{array}{l}\text { Journal of Construction Engineering and } \\
\text { Management }\end{array}$ & 14 \\
\hline $\begin{array}{l}\text { International Journal for Numerical Methods } \\
\text { in Engineering }\end{array}$ & 4 \\
\hline International Journal of Project Management & 4 \\
\hline Automation in Construction & 3 \\
\hline $\begin{array}{l}\text { Computer-Aided Civil and Infrastructure } \\
\text { Engineering }\end{array}$ & 3 \\
\hline Research Policy & 3 \\
\hline Journal of Aerospace Engineering & 2 \\
\hline & 2 \\
\hline Project Management Journal & 1 \\
\hline Advanced Engineering Informatics & 1 \\
\hline Journal of Computing in Civil Engineering & 1 \\
\hline Information and Control & 1 \\
\hline Journal of Marketing Research & 1 \\
\hline Journal of Structural Engineering & 1 \\
\hline Journal of The American Planning Association & 1 \\
\hline Journal of The Construction Division & 1 \\
\hline Long Range Planning & 1 \\
\hline Organization Studies & 1 \\
\hline Academy of Management Review & \\
\hline Scandinavian Journal of Management & \\
\hline
\end{tabular}

Table 4. Basic properties of the co-citations network

\begin{tabular}{|c|c|c|c|c|c|}
\hline & Nodes & Edges & $\begin{array}{c}\text { Average } \\
\text { Degree }\end{array}$ & Density & $\begin{array}{c}\text { Avg. Path } \\
\text { length }\end{array}$ \\
\hline $\begin{array}{c}\text { Whole } \\
\text { network }\end{array}$ & 67 & 311 & 9.701 & 0.147 & 3.801 \\
\hline Group 1 & 25 & 169 & 13.52 & 0.563 & 1.447 \\
\hline Group 2 & 8 & 14 & 3.5 & 0.5 & 1.607 \\
\hline Group 3 & 8 & 12 & 3 & 0.429 & 1.893 \\
\hline Group 4 & 4 & 6 & 3 & 1 & 1 \\
\hline Group 5 & 9 & 20 & 4.444 & 0.556 & 1.611 \\
\hline Group 6 & 13 & 61 & 9.385 & 0.782 & 1.256 \\
\hline
\end{tabular}

classics in this group, including Psychometric Theory (Numally, 1978), structural equation model (Fornell \& Larcker, 1981), case study (Eisenhardt, 1989; Yin, 1994), qualitative data analysis (Miles \& Huberman, 1984) and multivariate data analysis (Hair et al., 1998). Those classic theories and methods were introduced and applied for better understanding and mastering many aspects of construction projects, contributing to the reconceptualization of theory and practice of project management, rethinking the organization and management manner of the project, and advocating future research directions of project management. 


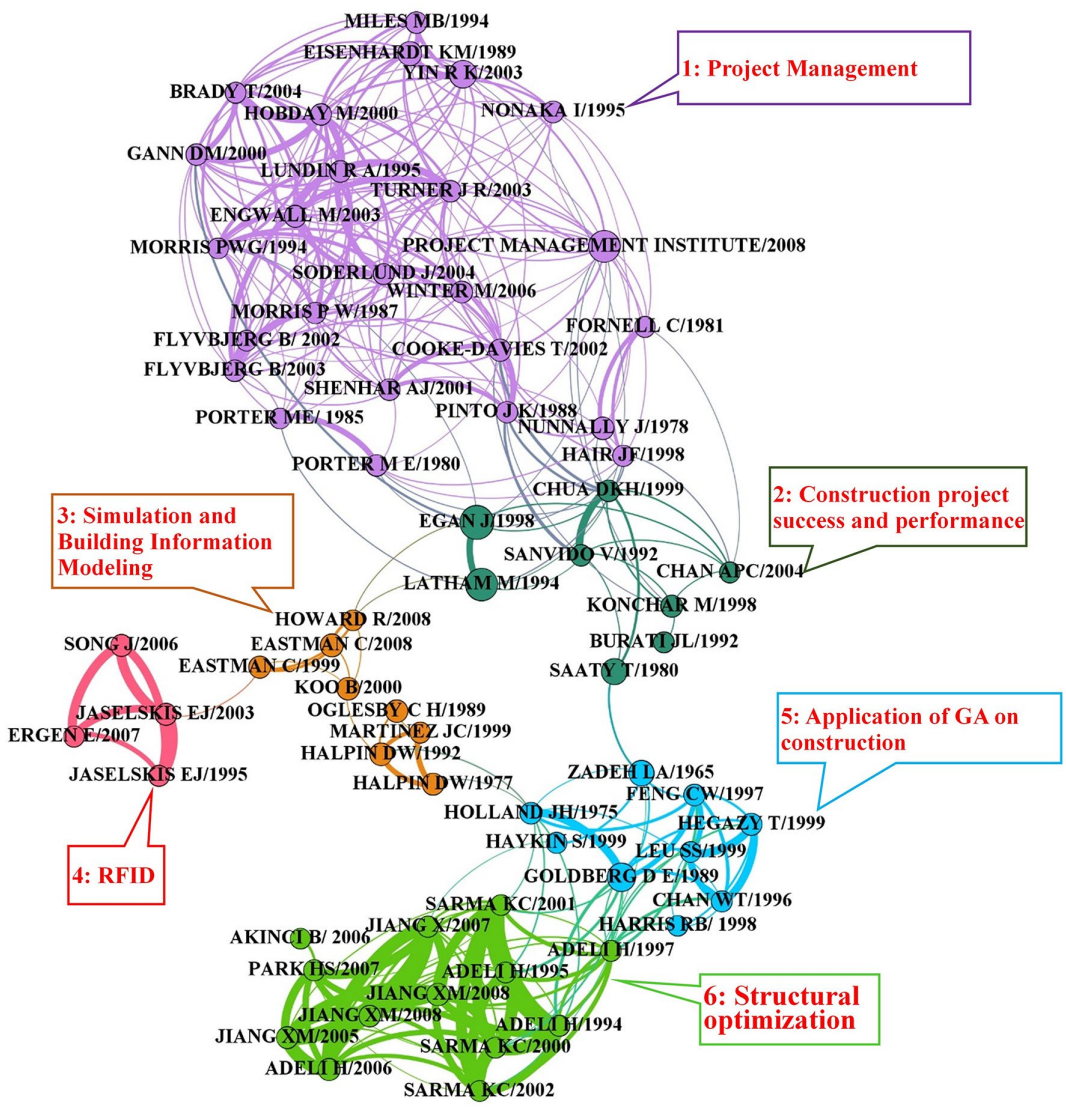

Figure 2. Classics co-citation network of CEM

Table 5. Classics in Group 1

\begin{tabular}{|c|c|c|c|c|c|c|}
\hline No. & LCC & Title & Author & Journal Name & $\begin{array}{l}\text { Document } \\
\text { type }\end{array}$ & Year \\
\hline 1 & 228 & $\begin{array}{l}\text { A guide to the project management body } \\
\text { of knowledge }\end{array}$ & PMI & I & BOOK & 1996 \\
\hline 2 & 158 & Case study research: design and methods & YIN R K & / & BOOK & 2003 \\
\hline 3 & 101 & Building theories from case study research & EISENHARDT KM & $\begin{array}{c}\text { ACADEMY OF } \\
\text { MANAGEMENT REVIEW }\end{array}$ & $\begin{array}{l}\text { JOURNAL } \\
\text { PAPER }\end{array}$ & 1989 \\
\hline 4 & 70 & Psychometric Theory & NUNNALLY J & & BOOK & 1978 \\
\hline 5 & 67 & The real success factors on projects & COOKE-DAVIES T & $\begin{array}{l}\text { INTERNATIONAL } \\
\text { JOURNAL OF PROJECT } \\
\text { MANAGEMENT }\end{array}$ & $\begin{array}{l}\text { JOURNAL } \\
\text { PAPER }\end{array}$ & 2002 \\
\hline 6 & 61 & $\begin{array}{l}\text { No project is an island: linking projects to } \\
\text { history and context }\end{array}$ & ENGWALL M & RES POLICY & $\begin{array}{l}\text { JOURNAL } \\
\text { PAPER }\end{array}$ & 2003 \\
\hline 7 & 60 & The Knowledge-Creating Company & NONAKA I & $\mathrm{BOOK}$ & BOOK & 1995 \\
\hline 8 & 59 & $\begin{array}{l}\text { Directions for future research in project } \\
\text { management: the main findings of a UK } \\
\text { government-funded research network }\end{array}$ & WINTER M & $\begin{array}{l}\text { INTERNATIONAL } \\
\text { JOURNAL OF PROJECT } \\
\text { MANAGEMENT }\end{array}$ & $\begin{array}{l}\text { JOURNAL } \\
\text { PAPER }\end{array}$ & 2006 \\
\hline 9 & 58 & $\begin{array}{l}\text { Project success: a multidimensional } \\
\text { strategic concept }\end{array}$ & SHENHAR AJ & LONG RANGE PLANNING & $\begin{array}{l}\text { JOURNAL } \\
\text { PAPER }\end{array}$ & 2001 \\
\hline 10 & 56 & $\begin{array}{l}\text { Competitive strategy: techniques for } \\
\text { analyzing industries and competitors }\end{array}$ & PORTER M E & I & $\mathrm{BOOK}$ & 1980 \\
\hline 11 & 56 & $\begin{array}{l}\text { Qualitative data analysis: A source book } \\
\text { of new methods }\end{array}$ & MILES MB & l & BOOK & 1984 \\
\hline 12 & 55 & A theory of temporary organization & LUNDIN R A & $\begin{array}{l}\text { SCANDINAVIAN } \\
\text { JOURNAL OF } \\
\text { MANAGEMENT }\end{array}$ & $\begin{array}{l}\text { JOURNAL } \\
\text { PAPER }\end{array}$ & 1995 \\
\hline
\end{tabular}


End of Table 5

\begin{tabular}{|c|c|c|c|c|c|c|}
\hline No. & LCC & Title & Author & Journal Name & $\begin{array}{l}\text { Document } \\
\text { type }\end{array}$ & Year \\
\hline 13 & 55 & $\begin{array}{l}\text { Innovation in project-based, service- } \\
\text { enhanced firms: the construction of } \\
\text { complex products and systems }\end{array}$ & GANN DM & RES POLICY & $\begin{array}{l}\text { JOURNAL } \\
\text { PAPER }\end{array}$ & 2000 \\
\hline 14 & 55 & MEGAPROJECTS RISK & FLYVBJERG B & l & BOOK & 2003 \\
\hline 15 & 55 & $\begin{array}{l}\text { On the nature of the project as a } \\
\text { temporary organization }\end{array}$ & TURNER J R & $\begin{array}{l}\text { INTERNATIONAL } \\
\text { JOURNAL OF PROJECT } \\
\text { MANAGEMENT }\end{array}$ & $\begin{array}{l}\text { JOURNAL } \\
\text { PAPER }\end{array}$ & 2003 \\
\hline 16 & 54 & $\begin{array}{l}\text { Project success: definitions and } \\
\text { measurement techniques }\end{array}$ & PINTO J K & PMJ & $\begin{array}{l}\text { JOURNAL } \\
\text { PAPER }\end{array}$ & 1988 \\
\hline 17 & 53 & $\begin{array}{l}\text { The anatomy of major projects a study of } \\
\text { the reality of project management }\end{array}$ & MORRIS P W & l & BOOK & 1987 \\
\hline 18 & 51 & Multivariate Data Analysis & HAIR JF & I & BOOK & 1998 \\
\hline 19 & 50 & $\begin{array}{l}\text { The project-based organisation: an ideal } \\
\text { form for managing complex products and } \\
\text { systems }\end{array}$ & HOBDAY M & RES POLICY & $\begin{array}{l}\text { JOURNAL } \\
\text { PAPER }\end{array}$ & 2000 \\
\hline 20 & 44 & $\begin{array}{l}\text { Evaluating structural equation models } \\
\text { with unobservable variables and } \\
\text { measurements error }\end{array}$ & FORNELL C & $\begin{array}{c}\text { JOURNAL OF } \\
\text { MARKETING RESEARCH }\end{array}$ & $\begin{array}{l}\text { JOURNAL } \\
\text { PAPER }\end{array}$ & 1981 \\
\hline 21 & 44 & $\begin{array}{l}\text { Building project capabilities: from } \\
\text { exploratory to exploitative learning }\end{array}$ & BRADY T & ORGANIZATION STUDIES & $\begin{array}{l}\text { JOURNAL } \\
\text { PAPER }\end{array}$ & 2004 \\
\hline 22 & 43 & $\begin{array}{l}\text { Building theories of project management: } \\
\text { past research, questions for the future }\end{array}$ & SODERLUND J & $\begin{array}{l}\text { INTERNATIONAL } \\
\text { JOURNAL OF PROJECT } \\
\text { MANAGEMENT }\end{array}$ & $\begin{array}{l}\text { JOURNAL } \\
\text { PAPER }\end{array}$ & 2004 \\
\hline 23 & 42 & The management of projects & MORRIS PWG & I & BOOK & 1994 \\
\hline 24 & 41 & $\begin{array}{l}\text { Competitive Advantage: Creating and } \\
\text { Sustaining Superior Performance }\end{array}$ & PORTER ME & I & BOOK & 1985 \\
\hline 25 & 41 & $\begin{array}{l}\text { Underestimating costs in public works } \\
\text { projects: Error or lie? }\end{array}$ & FLYVBJERG B & $\begin{array}{c}\text { JOURNAL OF THE } \\
\text { AMERICAN PLANNING } \\
\text { ASSOCIATION }\end{array}$ & $\begin{array}{l}\text { JOURNAL } \\
\text { PAPER }\end{array}$ & 2002 \\
\hline
\end{tabular}

Notes: Please see Table 1 for abbreviations used for Journals.

\subsubsection{Group 2: Construction project success and performance}

This group contains eight classics that mainly focus on construction project success, process, and performance, grasping the big picture of the construction industry status (Table 6). Therefore, those classics make a significant contribution to CEM research by highlighting the constraints and drawbacks of management practices in construction projects and stressing the need to improve the performance. The classics identified key factors that may lead to construction project success and pointed out how to improve the performance. The most striking works, in this group, are "Constructing the Team" and "Rethinking Construction", with substantially higher LCC than other classics. "Constructing the team" was recognized as the first serious discussion and analysis on the partnering and collaboration in the construction industry, highlighting the significant role of the client to achieve construction project success (Latham, 1994). "Rethinking construction", a report of Construction Task Force, emphasized the need to meet the new requirements of the construction industry (Egan, 1998). Moreover, aiming at performance improvements, this report proposed a framework for possible improvement in the construction industry.

\subsubsection{Group 3: Simulation and Building Information Modeling (BIM)}

Classics in this group mainly investigate on computer-aided models, including simulation tools (Halpin, 1977; Halpin \& Riggs, 1992; Martinez \& Ioannou, 1999) and BIM (Table 7). Those studies provided exciting opportunities to advance our knowledge about applying simulation tools on operations and management processes in construction. Halpin's two works, as the first language of modern construction simulation, systematically proposed a simulation technique - Cyclone. It is one of the general simulation tools, which is frequently used to model repetitive cycles of tasks in construction processes, such as concrete pouring and formwork layout.

Another classic is Koo's and Fischer's work, which developed a 4D Computer Aided Design (CAD) model, enabling the visualization of information flows through project organizations. Therefore, $4 \mathrm{D}$ CAD model is an alternative to construction project scheduling tools, adding construction processes and temporal information into the 3D model, which could support the collaboration and communication between construction project participants. By integrating with the 3D model, this model can be successfully adopted with intelligible visualizations, 
and thus the managers can easily generate, manipulate and validate the tool through a common medium (Koo \& Fischer, 2000).

BIM has been widely applied in the construction industry. The classic book "Building product models: Computer environments supporting design and construction" (Eastman, 1999) proposed a common model to integrate several tools in construction project communication. The solution, named "Building Product Modeling" in the first place, is widely recognized as a digital representation of building processes to facilitate exchange and information interoperability.

\subsubsection{Group 4: Radio-frequency identifications (RFID)}

This group contains four classic papers about the application of Radio-frequency identifications to the construction industry, especially on tracking and locating precast and fabricated storage components (Table 8). As the progress of the semiconductor fabrication technologies and nanotechnologies, the size of the sensors decreased whereas the cost went down dramatically, leading to the broad applications of the communication devices such as RFID to the industry, significantly altering the design, plan and construction processes. As a starting point, Jaselskis and El-Misalami (2003) introduced the RFID technology to the construction industry, in terms of delivery, billing and quality control for concrete. The primary advantage that the RFID has brought to the construction industry is that the process and schedule for concrete can be monitored and notified to job sites and testing labs. Those classics demonstrated how owners, contractors, and suppliers could enhance their operations by using RFID.

Table 6. Classics in Group 2

\begin{tabular}{|c|c|c|c|c|c|c|}
\hline No. & LCC & Title & Author & $\begin{array}{l}\text { Document } \\
\text { type }\end{array}$ & $\begin{array}{l}\text { Journal } \\
\text { Name }\end{array}$ & Year \\
\hline 1 & 264 & Rethinking Construction & EGAN J & REPORT & l & 1998 \\
\hline 2 & 239 & Constructing the team & LATHAM M & REPORT & I & 1994 \\
\hline 3 & 132 & The Analytical Hierarchy Process & SAATY T & BOOK & / & 1980 \\
\hline 4 & 62 & Comparison of U.S. project delivery systems & KONCHAR M & $\begin{array}{l}\text { JOURNAL } \\
\text { PAPER }\end{array}$ & JCEM-ASCE & 1998 \\
\hline 5 & 55 & Critical success factors for different project objectives & CHUA DKH & $\begin{array}{l}\text { JOURNAL } \\
\text { PAPER }\end{array}$ & JCEM-ASCE & 1999 \\
\hline 6 & 53 & Critical success factors for construction projects & SANVIDO V & $\begin{array}{l}\text { JOURNAL } \\
\text { PAPER }\end{array}$ & JCEM-ASCE & 1992 \\
\hline 7 & 42 & Causes of quality deviations in design and construction & BURATI JL & $\begin{array}{c}\text { JOURNAL } \\
\text { PAPER }\end{array}$ & JCEM-ASCE & 1992 \\
\hline 8 & 42 & $\begin{array}{l}\text { Exploring critical success factors for partnering in } \\
\text { construction projects }\end{array}$ & CHAN APC & $\begin{array}{l}\text { JOURNAL } \\
\text { PAPER }\end{array}$ & JCEM-ASCE & 2004 \\
\hline
\end{tabular}

Table 7. Classics in Group 3

\begin{tabular}{|c|c|c|c|c|c|c|}
\hline No. & LCC & Title & Author & $\begin{array}{l}\text { Document } \\
\text { type }\end{array}$ & Journal Name & Year \\
\hline 1 & 77 & $\begin{array}{l}\text { BIM handbook: A guide to building information } \\
\text { modeling for owners, managers, engineers, and } \\
\text { contractors }\end{array}$ & EASTMAN C & BOOK & / & 2008 \\
\hline 2 & 74 & Planning and analysis of construction operations & HALPIN DW & BOOK & l & 1992 \\
\hline 3 & 74 & $\begin{array}{l}\text { Feasibility study of } 4 \mathrm{D} \text { CAD in commercial } \\
\text { construction }\end{array}$ & KOO B & $\begin{array}{l}\text { JOURNAL } \\
\text { PAPER }\end{array}$ & JCEM-ASCE & 2000 \\
\hline 4 & 69 & Productivity improvement in construction & OGLESBY C H & BOOK & / & 1989 \\
\hline 5 & 63 & $\begin{array}{l}\text { CYCLONE: Method for modeling of job site } \\
\text { processes }\end{array}$ & HALPIN DW & $\begin{array}{l}\text { JOURNAL } \\
\text { PAPER }\end{array}$ & $\begin{array}{l}\text { JOURNAL OF THE } \\
\text { CONSTRUCTION } \\
\text { DIVISION } \\
\end{array}$ & 1977 \\
\hline 6 & 63 & $\begin{array}{l}\text { Building product models: Computer environments } \\
\text { supporting design and construction }\end{array}$ & EASTMAN C & BOOK & l & 1999 \\
\hline 7 & 44 & $\begin{array}{l}\text { General-purpose systems for effective construction } \\
\text { simulation }\end{array}$ & MARTINEZ JC & $\begin{array}{l}\text { JOURNAL } \\
\text { PAPER }\end{array}$ & JCEM-ASCE & 1999 \\
\hline 8 & 42 & $\begin{array}{l}\text { Building information modelling Experts views on } \\
\text { standardisation and industry deployment }\end{array}$ & HOWARD R & $\begin{array}{l}\text { JOURNAL } \\
\text { PAPER }\end{array}$ & AEI & 2008 \\
\hline
\end{tabular}


Table 8. Classics in Group 4

\begin{tabular}{|c|c|c|c|c|c|c|}
\hline No. & LCC & Title & Author & Document type & Journal name & Year \\
\hline 1 & 59 & $\begin{array}{l}\text { Automating the task of tracking the delivery and receipt } \\
\text { of fabricated pipe spools in industrial projects }\end{array}$ & SONG J & JOURNAL PAPER & AIC & 2006 \\
\hline 2 & 57 & $\begin{array}{l}\text { Implementing radio frequency identification in the } \\
\text { construction process }\end{array}$ & JASELSKIS EJ & JOURNAL PAPER & JCEM-ASCE & 2003 \\
\hline 3 & 48 & $\begin{array}{l}\text { Tracking and locating components in a precast storage } \\
\text { yard utilizing radio frequency identification technology } \\
\text { and GPS }\end{array}$ & ERGEN E & JOURNAL PAPER & AIC & 2007 \\
\hline 4 & 42 & $\begin{array}{l}\text { Radio-frequency identifications applications in } \\
\text { construction industry }\end{array}$ & JASELSKIS EJ & JOURNAL PAPER & JCEM-ASCE & 1995 \\
\hline
\end{tabular}

Table 9. Classics in Group 5

\begin{tabular}{|c|c|l|c|c|c|c|}
\hline No. & LCC & \multicolumn{1}{|c|}{ Title } & Author & Document type & Journal name & Year \\
\hline 1 & 170 & $\begin{array}{l}\text { Genetic Algorithms in Search, Optimization, } \\
\text { and Machine Learning }\end{array}$ & GOLDBERG D E & BOOK & 1 \\
\hline 2 & 120 & Fuzzy sets & ZADEH LA & JOURNAL PAPER & $\begin{array}{c}\text { INFORMATION } \\
\text { AND } \\
\text { CONTROL }\end{array}$ & $\begin{array}{c}1965 \\
\text { CONG }\end{array}$ \\
\hline 3 & 62 & $\begin{array}{l}\text { Optimization of resource allocation and leveling } \\
\text { using genetic algorithms }\end{array}$ & HEGAZY T & JOURNAL PAPER & JCEM-ASCE & 1999 \\
\hline 4 & 58 & Adaptation in natural and artificial systems & HOLLAND JH & BOOK & $/$ & CCE \\
\hline 5 & 57 & $\begin{array}{l}\text { Using genetic algorithms to solve construction } \\
\text { time-cost trade-off problems }\end{array}$ & FENG CW & JOURNAL PAPER & 1997 \\
\hline 6 & 49 & $\begin{array}{l}\text { Construction resource scheduling with genetic } \\
\text { algorithms }\end{array}$ & CHAN WT & JOURNAL PAPER & JCEM-ASCE & 1996 \\
\hline 7 & 46 & Neural networks: A comprehensive foundation & HAYKIN S & BOOK & $/$ \\
\hline 8 & 42 & $\begin{array}{l}\text { GA-based multicriteria optimal model for } \\
\text { construction scheduling }\end{array}$ & LEU SS & JOURNAL PAPER & JCEM-ASCE & 1999 \\
\hline 9 & 41 & Scheduling projects with repeating activities & HARRIS RB & JOURNAL PAPER & JCEM-ASCE & 1998 \\
\hline
\end{tabular}

\subsubsection{Group 5: Applications of Genetic Algorithm (GA) in construction}

The classics in this group mainly introduce a useful approach - GA to the construction industry (Table 9). Publications about mathematics methods, such as fuzzy sets (Zadeh, 1965) and genetic algorithm (Golberg, 1989; Holland, 1975), are identified as classics in this group. As a useful approach, the genetic algorithm was used to support the optimization of design configurations for everything from earthmoving fleets to project organizations. For example, it was applied to the construction industry in terms of dealing with time-cost and trade-off problems (Feng et al., 1997), facilitating scheduling (Harris \& Ioannou, 1998; Leu \& Yang, 1999) and optimization of resource allocation and leveling (Hegazy, 1999). Those findings made important contributions to optimizing construction operations and processes.

\subsubsection{Group 6: Structural optimization}

This group includes 13 journal papers as classics (Table 10), mainly providing knowledge about structural optimization (Adeli \& Cheng, 1994; Adeli \& Kumar, 1995). Owing to the enormous number of parameters in the large structure, genetic algorithms, neural networks, and dynamic fuzzy wavelet have been developed and applied to improve the size of the structure.

\section{Summary and conclusions}

This study explores the classics that significantly contribute to the CEM research. Moreover, the underlying structure of the CEM classics was identified. The results suggest that CEM research was largely driven by classic theories and methods of other fields. For example, some theories of social science and research methods of management constitute the classics of project management (group 1). Similar trends can be observed in radio-frequency identifications (RFID) (group 4), applications of Genetic Algorithm (GA) in construction (group 5) and structural optimization (group 6). Those classics can help the researchers of CEM have better comprehensive management in construction practice, serving as paradigms to investigate the management issues in construction. The results also indicate that the works that conducted depth summarization of confused phenomena and problems in the construction industry and provided novel views to rethink these problems probably become a classic. For example, the classic 
Table 10. Classics in Group 6

\begin{tabular}{|c|c|c|c|c|c|c|}
\hline No. & LCC & Title & Author & $\begin{array}{l}\text { Document } \\
\text { type }\end{array}$ & Journal name & Year \\
\hline 1 & 71 & $\begin{array}{l}\text { Neuro-genetic algorithm for nonlinear } \\
\text { active control of highrise buildings }\end{array}$ & JIANG XM & $\begin{array}{l}\text { JOURNAL } \\
\text { PAPER }\end{array}$ & $\begin{array}{l}\text { INTERNATIONAL JOURNAL FOR } \\
\text { NUMERICAL METHODS } \\
\text { IN ENGINEERING }\end{array}$ & 2008 \\
\hline 2 & 64 & Managing the flow of technology & ADELI H & BOOK & I & 2006 \\
\hline 3 & 57 & $\begin{array}{l}\text { Dynamic wavelet neural network for } \\
\text { nonlinear identification of highrise } \\
\text { buildings }\end{array}$ & JIANG XM & $\begin{array}{l}\text { JOURNAL } \\
\text { PAPER }\end{array}$ & CCIE & 2005 \\
\hline 4 & 54 & $\begin{array}{l}\text { Dynamic fuzzy wavelet neuroemulator } \\
\text { for nonlinear control of irregular highrise } \\
\text { building structures }\end{array}$ & JIANG XM & $\begin{array}{l}\text { JOURNAL } \\
\text { PAPER }\end{array}$ & $\begin{array}{l}\text { INTERNATIONAL JOURNAL FOR } \\
\text { NUMERICAL METHODS } \\
\text { IN ENGINEERING }\end{array}$ & 2008 \\
\hline 5 & 51 & $\begin{array}{l}\text { A new approach for health monitoring of } \\
\text { structures: Terrestrial laser scanning }\end{array}$ & PARK HS & $\begin{array}{l}\text { JOURNAL } \\
\text { PAPER }\end{array}$ & CCIE & 2007 \\
\hline 6 & 50 & $\begin{array}{l}\text { Pseudospectra, MUSIC, and dynamic } \\
\text { wavelet neural network for damage } \\
\text { detection of highrise buildings }\end{array}$ & JIANG X & $\begin{array}{l}\text { JOURNAL } \\
\text { PAPER }\end{array}$ & $\begin{array}{c}\text { INTERNATIONAL JOURNAL FOR } \\
\text { NUMERICAL METHODS } \\
\text { IN ENGINEERING } \\
\end{array}$ & 2007 \\
\hline 7 & 44 & $\begin{array}{l}\text { Concurrent genetic algorithms for } \\
\text { optimization of large structures }\end{array}$ & ADELI H & $\begin{array}{l}\text { JOURNAL } \\
\text { PAPER }\end{array}$ & $\begin{array}{l}\text { JOURNAL OF AEROSPACE } \\
\text { ENGINEERING }\end{array}$ & 1994 \\
\hline 8 & 44 & $\begin{array}{l}\text { Scheduling cost optimisation and neural } \\
\text { dynamics model for construction }\end{array}$ & ADELI H & $\begin{array}{l}\text { JOURNAL } \\
\text { PAPER }\end{array}$ & JCEM-ASCE & 1997 \\
\hline 9 & 44 & $\begin{array}{l}\text { Life-cycle cost optimization of steel } \\
\text { structures }\end{array}$ & SARMA KC & $\begin{array}{l}\text { JOURNAL } \\
\text { PAPER }\end{array}$ & $\begin{array}{c}\text { INTERNATIONAL JOURNAL FOR } \\
\text { NUMERICAL METHODS } \\
\text { IN ENGINEERING } \\
\end{array}$ & 2002 \\
\hline 10 & 43 & $\begin{array}{l}\text { Distributed genetic algorithms for } \\
\text { structural optimization }\end{array}$ & ADELI H & $\begin{array}{l}\text { JOURNAL } \\
\text { PAPER }\end{array}$ & $\begin{array}{c}\text { JOURNAL OF AEROSPACE } \\
\text { ENGINEERING }\end{array}$ & 1995 \\
\hline 11 & 43 & $\begin{array}{l}\text { Fuzzy genetic algorithm for optimization } \\
\text { of steel structures }\end{array}$ & SARMA KC & $\begin{array}{l}\text { JOURNAL } \\
\text { PAPER }\end{array}$ & $\begin{array}{c}\text { JOURNAL OF STRUCTURAL } \\
\text { ENGINEERING }\end{array}$ & 2000 \\
\hline 12 & 42 & $\begin{array}{l}\text { Bi-level parallel genetic algorithms for } \\
\text { optimization of large steel structures }\end{array}$ & SARMA KC & $\begin{array}{l}\text { JOURNAL } \\
\text { PAPER }\end{array}$ & CCIE & 2001 \\
\hline 13 & 41 & $\begin{array}{l}\text { A formalism for utilization of sensor } \\
\text { systems and integrated project models for } \\
\text { active construction quality control }\end{array}$ & AKINCI B & $\begin{array}{l}\text { JOURNAL } \\
\text { PAPER }\end{array}$ & AIC & 2006 \\
\hline
\end{tabular}

"Constructing the team" (Latham, 1994) in construction project success and performance (group 2) seriously discussed partnering and collaboration and highlighted the significant role of the client to achieve construction project success.

To effectively identify the classics of CEM, an integrated approach is developed to offset certain drawbacks that always occurred in previous studies. Although it is a tough task to use quantitative techniques to explore the classics due to the ambiguous definition and complex property, the proposed approach provides more persuasive results and can be used by scholars to identify classics in other academic fields of CEM. In specific, this study outlines two major contributions as follow:

(1) The aim of the present study has been to identify classics for the CEM field as a whole. As an academic field, CEM emerged and developed for a long time. It is widely recognized as an inter-discipline, absorbing and applying knowledge from other disciplines. In the field of CEM, several attempts have been made to identify the classics, but they only focus on the subfields. Alternatively, this study identifies CEM classics, representing the theoretical and rational foundations of the whole academic field and help researchers recognize the key scientific contributions to stimulate the academic development of CEM.

(2) To identify the classics of CEM with more precise and robust results, the authors develop an integrated approach that overcomes certain drawbacks in previous studies. The existing research has tended to focus on identifying classics from papers, but high-impact publications always appear in the references, not the papers. In addition, the classics were always identified by applying an arbitrary value (e.g., top 50 or 100 cited papers) rather than a systemic index. In the CEM area, previous studies have made some efforts to analyze the classics, but most of them failed to provide robust and convinced outputs as they do not overcome the limitations mentioned above. The approach proposed by this paper, takes the drawbacks mentioned above into consideration, and thus provides persuasive results about the classics for CEM. Moreover, most recent attention has focused on interpreting the classics' impacts on the subsequent research based on manual reviewing and personal judgments. Such expositions may be unsatisfactory as they failed to draw a whole picture for CEM 
that uncovers the underlying connections between different subareas of CEM. More than merely presenting the classics of CEM, this study uncovers the structure of the classics by using co-citation and modularity optimization algorithm, taking the underlying associations between the classics into consideration.

The study is not without limitations. As the definition does not provide explicit statements about the properties of classics, the criteria for the measurement is still lacking. Although citation is widely used to measure the classics for certain fields, there is some controversy in the citation over whether it provides convinced assessment for the scientific performance. In addition, the classics are not prelabeled, and thus the statistical validation for the methods can not be used. The current study offsets this limitation to some extent, by proposing an advanced approach to overcome some of the drawbacks of the citation analysis that has been widely used in previous studies. The authors also advocate further studies to address the limitations. In particular, advanced machine learning and natural language processing techniques may be used to discern the citing behavior by understanding the content where the citation appears.

\section{Acknowledgements}

We are grateful for the extremely helpful feedback we received from Boyu Zhang, Xiao Li, Juan Huang, Xue Lin, Bingxia Sun, Lizi Luo, and other members of the Sustainable Construction Lab, The Hong Kong Polytechnic University, Hong Kong.

\section{Funding}

This research was supported by the National Social Science Fund of China under Grant No. 18ZDA043. The work described in this paper was also funded by the $\mathrm{Na}$ tional Natural Science Foundation of China (NSFC) under Grant NO. 71671053, NO. 71771067, NO. 71841024, the National Key R\&D Program of China under Grant No. 2016YFC0701800 and No. 2016YFC0701808, and the Guangdong Science and Technology Program under Grant No. 2019B101001019.

\section{Author contributions}

All authors were involved in conceiving the study, data analysis and structure of the paper. Hengqin WU conducted scientific research, performed data analysis, and wrote the paper. Zebin ZHAO, Xiaolong XUE and Geoffrey Qiping SHEN reviewed and edited the manuscript drafts. Rebecca Jing YANG and Luqi WANG polished the language and checked the grammatical errors.

\section{Disclosure statement}

The authors do not have any competing financial, professional, or personal interests from other parties.

\section{References}

Acedo, F. J., \& Casillas, J. C. (2005). Current paradigms in the international management field: An author co-citation analysis. International Business Review, 14(5), 619-639.

https://doi.org/10.1016/j.ibusrev.2005.05.003

Adeli, H., \& Cheng, N.-T. (1994). Concurrent genetic algorithms for optimization of large structures. Journal of Aerospace Engineering, 7(3), 276-296.

https://doi.org/10.1061/(ASCE)0893-1321(1994)7:3(276)

Adeli, H., \& Kumar, S. (1995). Distributed genetic algorithm for structural optimization. Journal of Aerospace Engineering, 8(3), 156-163.

https://doi.org/10.1061/(ASCE)0893-1321(1995)8:3(156)

Ajiferuke, I., Lu, K., \& Wolfram, D. (2010). A comparison of citer and citation-based measure outcomes for multiple disciplines. Journal of the American Society for Information Science \& Technology, 61(10), 2086-2096. https://doi.org/10.1002/asi.21383

Aksnes, D. W. (2003). Characteristics of highly cited papers. Research Evaluation, 12(3), 159-170. https://doi.org/10.3152/147154403781776645

Aksnes, D. W., \& Sivertsen, G. (2004). The effect of highly cited papers on national citation indicators. Scientometrics, 59(2), 213224. https://doi.org/10.1023/B:SCIE.0000018529.58334.eb

Aminian, S., Hinckson, E. A., \& Stewart, T. (2015). Modifying the classroom environment to increase standing and reduce sitting. Building Research and Information, 43(5), 631-645. https://doi.org/10.1080/09613218.2015.1058093

Baltussen, A., \& Kindler, C. H. (2004). Citation classics in anesthetic journals. Anesthesia and Analgesia, 98(2), 443-451. https://doi.org/10.1213/01.ANE.0000096185.13474.0A

Brandt, J. S., Downing, A. C., Howard, D. L., Kofinas, J. D., \& Chasen, S. T. (2010). Citation classics in obstetrics and gynecology: the 100 most frequently cited journal articles in the last 50 years. American Journal of Obstetrics and Gynecology, 203(4), 355-362. https://doi.org/10.1016/j.ajog.2010.07.025

Buschman, M., \& Michalek, A. (2013). Are alternative metrics still alternative? Bulletin of the American Society for Information Science \& Technology, 39(4), 35-39.

https://doi.org/10.1002/bult.2013.1720390411

Cano, V., \& Lind, N. C. (1991). Citation life cycles of ten citation classics. Scientometrics, 22(2), 297-312. https://doi.org/10.1007/BF02020003

Charvet, F. F., Cooper, M. C., \& Gardner, J. T. (2008). The intellectual structure of supply chain management: A bibliometric approach. Journal of Business Logistics, 29(1), 47-73. https://doi.org/10.1002/j.2158-1592.2008.tb00068.x

Chen, C. M. (2004). Searching for intellectual turning points: Progressive knowledge domain visualization. Proceedings of the National Academy of Sciences of the United States of America, 101, 5303-5310. https://doi.org/10.1073/pnas.0307513100

Chinn, P. L. (2015). The value of classic literature in shaping the future. Advances in Nursing Science, 38(2), 69-69. https://doi.org/10.1097/ANS.0000000000000064

Chong, H. Y., Tan, C. K., \& Munir, O. (2015). Revisiting UK delay and disruption protocol: Distinguished features for contract drafting. Journal of Management in Engineering, 31(4), 06014004 . https://doi.org/10.1061/(ASCE)ME.1943-5479.0000299

Cooke-Davies, T. (2002). The "real" success factors on projects. International Journal of Project Management, 20(3), 185-190. https://doi.org/10.1016/S0263-7863(01)00067-9 
Costas, R., \& Bordons, M. (2008). Is g-index better than h-index? An exploratory study at the individual level. Scientometrics, 77(2), 267-288. https://doi.org/10.1007/s11192-007-1997-0

D’Agostino, B. (2017). Journal of Construction Engineering and Management and Construction Management: A journal and a profession grow together. Journal of Construction Engineering and Management, 143(9), 02517004.

https://doi.org/10.1061/(ASCE)CO.1943-7862.0001371

De Solla Price, D. (1976). A general theory of bibliometric and other cumulative advantage processes. Journal of the American Society for Information Science and Technology, 27, 292306. https://doi.org/10.1002/asi.4630270505

Eastman, C. M. (1999). Building product models: computer environments, supporting design and construction. CRC press.

Egan, J. (1998). Rethinking construction, construction task force report for department of the environment, transport and the regions. London: HMSO.

Egghe, L. (2005a). Power laws in the information production process: Lotkaian informetrics. Emerald Group Publishing Limited. https://doi.org/10.1108/S1876-0562(2005)05

Egghe, L. (2005b). The power of power laws and an interpretation of lotkaian informetric systems as self-similar fractals. Journal of the American Society for Information Science and Technology, 56(7), 669-675. https://doi.org/10.1002/asi.20158

Egghe, L. (2006). Theory and practise of the g-index. Scientometrics, 69(1), 131-152.

https://doi.org/10.1007/s11192-006-0144-7

Egghe, L. (2009). Lotkaian informetrics and applications to social networks. Bulletin of the Belgian Mathematical SocietySimon Stevin, 16(4), 689-703.

https://doi.org/10.36045/bbms/1257776242

Eisenhardt, K. M. (1989). Building theories from case-study research. Academy of Management Review, 14(4), 532-550. https://doi.org/10.5465/amr.1989.4308385

Feng, C.-W., Liu, L., \& Burns, S. A. (1997). Using genetic algorithms to solve construction time-cost trade-off problems. Journal of Computing in Civil Engineering, 11(3), 184-189. https://doi.org/10.1061/(ASCE)0887-3801(1997)11:3(184)

Fernandez-Alles, M., \& Ramos-Rodríguez, A. (2009). Intellectual structure of human resources management research: A bibliometric analysis of the journal Human Resource Management, 1985-2005. Journal of the American Society for Information Science and Technology, 60(1), 161-175. https://doi.org/10.1002/asi.20947

Floricel, S., Michela, J. L., \& Piperca, S. (2016). Complexity, uncertainty-reduction strategies, and project performance. International Journal of Project Management, 34(7), 1360-1383. https://doi.org/10.1016/j.ijproman.2015.11.007

Flyvbjerg, B. (2014). What you should know about megaprojects and why: An overview. Project Management Journal, 45(2), 6-19. https://doi.org/10.1002/pmj.21409

Flyvbjerg, B., Holm, M. S., \& Buhl, S. (2002). Underestimating costs in public works projects - Error or lie? Journal of the American Planning Association, 68(3), 279-295. https://doi.org/10.1080/01944360208976273

Flyvbjerg, B., \& Turner, J. R. (2018). Do classics exist in megaproject management? International Journal of Project Management, 36(2), 334-341.

https://doi.org/10.1016/j.ijproman.2017.07.006

Fornell, C., \& Larcker, D. F. (1981). Evaluating structural equation models with unobservable variables and measurement error. Journal of Marketing Research, 18(1), 39-50.

https://doi.org/10.1177/002224378101800104
Garfield, E. (1976). Citation analysis, mechanical translation of chemical nomenclature, and the macrostructure of science. Journal of Chemical Information and Modeling, 15(5), 153155. https://doi.org/10.1021/ci60003a005

Garfield, E. (1977). Introducing citation classics. The human side of scientific reports. Current Contents, 1, 5-7.

Gellert, P. K., \& Lynch, B. D. (2003). Mega-projects as displacements. International Social Science Journal, 55(1), 15-25. https://doi.org/10.1111/1468-2451.5501002

Gmur, M. (2003). Co-citation analysis and the search for invisible colleges: A methodological evaluation. Scientometrics, 57(1), 27-57. https://doi.org/10.1023/A:1023619503005

Golberg, D. E. (1989). Genetic algorithms in search, optimization, and machine learning. Addion Wesley.

Hair, J. F., Black, W. C., Babin, B. J., Anderson, R. E., \& Tatham, R. L. (1998). Multivariate data analysis. Prentice Hall.

Halpin, D. W. (1977). CYCLONE-method for modeling job site processes. Journal of the Construction Division, 103(3), 489-499.

Halpin, D. W., \& Riggs, L. S. (1992). Planning and analysis of construction operations. John Wiley \& Sons.

Harris, R. B., \& Ioannou, P. G. (1998). Scheduling projects with repeating activities. Journal of Construction Engineering and Management, 124(4), 269-278.

https://doi.org/10.1061/(ASCE)0733-9364(1998)124:4(269)

Hegazy, T. (1999). Optimization of resource allocation and leveling using genetic algorithms. Journal of Construction Engineering and Management, 125(3), 167-175.

https://doi.org/10.1061/(ASCE)0733-9364(1999)125:3(167)

Hirsch, J. E. (2005). An index to quantify an individual's scientific research output. Proceedings of the National Academy of Sciences of the United States of America, 102(46), 16569-16572. https://doi.org/10.1073/pnas.0507655102

Hirsch, J. E. (2007). Does the h index have predictive power? Proceedings of the National Academy of Sciences, 104(49), 19193-19198. https://doi.org/10.1073/pnas.0707962104

Ho, Y. S. (2012). Top-cited articles in chemical engineering in Science Citation Index Expanded: A bibliometric analysis. Chinese Journal of Chemical Engineering, 20(3), 478-488. https://doi.org/10.1016/S1004-9541(11)60209-7

Ho, Y. S. (2014). Classic articles on social work field in Social Science Citation Index: a bibliometric analysis. Scientometrics, 98(1), 137-155. https://doi.org/10.1007/s11192-013-1014-8

Hobday, M. (2000). The project-based organisation: an ideal form for managing complex products and systems? Research Policy, 29(7-8), 871-893. https://doi.org/10.1016/S0048-7333(00)00110-4

Holland, J. H. (1975). Adaptation in natural and artificial systems. An introductory analysis with application to biology, control, and artificial intelligence. University of Michigan Press.

Huang, J. H., Dong, Z. X., Quan, L., Jin, Z. F., Lan, Y., \& Wang, Y. J. (2015). Development of a dual displacement controlled circuit for hydraulic shovel swing motion. Automation in Construction, 57, 166-174. https://doi.org/10.1016/j.autcon.2015.06.006

Ibrahim, G. M., Snead, O. C., Rutka, J. T., \& Lozano, A. M. (2012). The most cited works in epilepsy: Trends in the "Citation Classics". Epilepsia, 53(5), 765-770. https://doi.org/10.1111/j.1528-1167.2012.03455.x

Jaselskis, E. J., \& El-Misalami, T. (2003). Implementing radio frequency identification in the construction process. Journal of Construction Engineering and Management, 129(6), 680-688. https://doi.org/10.1061/(ASCE)0733-9364(2003)129:6(680) 
Kelly, J. C., Glynn, R. W., O’Briain, D. E., Felle, P., \& McCabe, J. P. (2010). The 100 classic papers of orthopaedic surgery: A bibliometric analysis. The Journal of Bone and Joint Surgery - British Volume, 92B(10), 1338-1343.

https://doi.org/10.1302/0301-620X.92B10.24867

Kennedy, L. (2015). The politics and changing paradigm of megaproject development in metropolitan cities. Habitat International, 45, 163-168.

https://doi.org/10.1016/j.habitatint.2014.07.001

Koo, B., \& Fischer, M. (2000). Feasibility study of 4D CAD in commercial construction. Journal of Construction Engineering and Management, 126(4), 251-260.

https://doi.org/10.1061/(ASCE)0733-9364(2000)126:4(251)

Korevaar, J. C., \& Moed, H. F. (1996). Validation of bibliometric indicators in the field of mathematics. Scientometrics, 37(1), 117-130. https://doi.org/10.1007/BF02093488

Kuhn, T. S. (1962). The structure of scientific revolutions. University of Chicago Press.

Latham, S. M. (1994). Constructing the team. HM Stationery Office London.

Laurance, W. F., Clements, G. R., Sloan, S., O'Connell, C. S., Mueller, N. D., Goosem, M., Venter, O., Edwards, D. P., Phalan, B., Balmford, A., Van Der Ree, R., \& Arrea, I. B. (2014). A global strategy for road building. Nature, 513, 229-232. https://doi.org/10.1038/nature13717

Leu, S.-S., \& Yang, C.-H. (1999). GA-based multicriteria optimal model for construction scheduling. Journal of Construction Engineering and Management, 125(6), 420-427. https://doi.org/10.1061/(ASCE)0733-9364(1999)125:6(420)

Levitt, R. E. (2007). CEM research for the next 50 years: Maximizing economic, environmental, and societal value of the built environment. Journal of Construction Engineering and Management, 133(9), 619-628.

https://doi.org/10.1061/(ASCE)0733-9364(2007)133:9(619)

Leydesdorff, L., Wagner, C. S., \& Bornmann, L. (2014). The European Union, China, and the United States in the top-1\% and top-10\% layers of most-frequently cited publications: Competition and collaborations. Journal of Informetrics, 8(3), 606-617. https://doi.org/10.1016/j.joi.2014.05.002

Li, Y., Lu, Y., Taylor, J. E., \& Han, Y. (2017). Bibliographic and comparative analyses to explore emerging classic texts in megaproject management. International Journal of Project Management, 36(2), 342-361.

https://doi.org/10.1016/j.ijproman.2017.05.008

Lin, G. B., \& Shen, Q. P. (2007). Measuring the performance of value management studies in construction: Critical review. Journal of Management in Engineering, 23(1), 2-9. https://doi.org/10.1061/(ASCE)0742-597X(2007)23:1(2)

Lo, K. K. H., Wong, A. H. C., Tam, W. W. S., \& Ho, S. C. (2016). Citation classics in the nutrition and dietetics literature: 50 frequently cited articles. Nutrition \& Dietetics, 73(4), 356-368. https://doi.org/10.1111/1747-0080.12173

Long, X., Huang, J. Z., \& Ho, Y. S. (2014). A historical review of classic articles in surgery field. American Journal of Surgery, 208(5), 841-849.

https://doi.org/10.1016/j.amjsurg.2014.03.016

Lorenz, M. O. (1905). Methods of measuring the concentration of wealth. Publications of the American Statistical Association, 9, 209-219. https://doi.org/10.2307/2276207

Lowry, P., Romans, D., \& Curtis, A. (2004). Global journal prestige and supporting disciplines: A scientometric study of Information systems journals. Journal of the Association for Information Systems, 5(2), 29-80. https://doi.org/10.17705/1jais.00045
Lu, Y. J., Li, Y. K., Skibniewski, M., Wu, Z. L., Wang, R. S., \& Le, Y. (2015). Information and communication technology applications in architecture, engineering, and construction organizations: A 15-year review. Journal of Management in Engineering, 31(1), A4014010.

https://doi.org/10.1061/(ASCE)ME.1943-5479.0000319

Lundin, R. A., \& Söderholm, A. (1995). A theory of the temporary organization. Scandinavian Journal of Management, 11(4), 437-455.

https://doi.org/10.1016/0956-5221(95)00036-U

Martinez, J. C., \& Ioannou, P. G. (1999). General-purpose systems for effective construction simulation. Journal of Construction Engineering and Management, 125(4), 265-276. https://doi.org/10.1061/(ASCE)0733-9364(1999)125:4(265)

Martinez, M., Herrera, M., Contreras, E., Ruiz, A., \& HerreraViedma, E. (2015). Characterizing highly cited papers in Social Work through H-Classics. Scientometrics, 102(2), 17131729. https://doi.org/10.1007/s11192-014-1460-y

McCain, K. W. (1990). Mapping authors in intellectual space: A technical overview. Journal of the American Society for Information Science, 41(6), 433-443. https://doi.org/10.1002/ (SICI)1097-4571(199009)41:6<433::AID-ASI11>3.0.CO;2-Q

McLeskey, J. (2004). Classic articles in special education - Articles that shaped the field, 1960 to 1996. Remedial and Special Education, 25(2), 79-87. https://doi.org/10.1177/07419325040250020201

Meho, L. I., \& Yang, K. (2007). Impact of data sources on citation counts and rankings of LIS faculty: Web of Science versus Scopus and Google Scholar. Journal of the American Society for Information Science and Technology, 58(13), 2105-2125. https://doi.org/10.1002/asi.20677

Miles, M., \& Huberman, A. M. (1984). Qualitative data analysis: A source book of new methods. SAGE Publications, Inc.

Morse, L. C., \& Babcock, D. L. (2010). Managing engineering and technology: An introduction to management for engineers. Prentice Hall.

Newman, M. E. J. (2004). Analysis of weighted networks. Physical Review E, 70(5), 056131.

https://doi.org/10.1103/PhysRevE.70.056131

Newman, M. E. J. (2006). Modularity and community structure in networks. Proceedings of the National Academy of Sciences of the United States of America, 103(23), 8577-8582.

https://doi.org/10.1073/pnas.0601602103

Numally, J. C. (1978). Psychometric theory. McGraw-Hill.

Olawumi, T. O., Chan, D. W. M., \& Wong, J. K. W. (2017). Evolution in the intellectual structure of BIM research: A bibliometric analysis. Journal of Civil Engineering and Management, 23(8), 1060-1081. https://doi.org/10.3846/13923730.2017.1374301

Perianes-Rodriguez, A., Waltman, L., \& van Eck, N. J. (2016). Constructing bibliometric networks: A comparison between full and fractional counting. Journal of Informetrics, 10(4), 1178-1195. https://doi.org/10.1016/j.joi.2016.10.006

Pilkington, A. (2008). Engineering management or management of technology? A bibliometric study of IEEE TEM. International Journal of Management Science and Engineering Management, 3(1), 63-70.

https://doi.org/10.1080/17509653.2008.10671036

Pinto, J., \& Slevin, D. P. (1988). Project success: definitions and measurement techniques. Project Management Journal, 19(1), $67-71$.

Powell, M. (2016). Citation classics in social policy journals. Social Policy \& Administration, 50(6), 648-672.

https://doi.org/10.1111/spol.12254 
Ramos-Rodriguez, A. R., \& Ruiz-Navarro, J. (2004). Changes in the intellectual structure of strategic management research: A bibliometric study of the Strategic Management Journal, 1980-2000. Strategic Management Journal, 25(10), 981-1004. https://doi.org/10.1002/smj.397

Satty, T. L. (1980). The analytical hierarchy process: planning, priority setting, resource allocation. McGraw-Hill.

Scott, J. (2012). Social network analysis. Sage. https://doi.org/10.1007/978-1-4614-1800-9_178

Seglen, P. O. (1998). Citation rates and journal impact factors are not suitable for evaluation of research. Acta Orthopaedica Scandinavica, 69(3), 224-229. https://doi.org/10.3109/17453679809000920

Serenko, A., \& Dumay, J. (2015). Citation classics published in knowledge management journals. Part I: articles and their characteristics. Journal of Knowledge Management, 19(2), 401-431. https://doi.org/10.1108/JKM-06-2014-0220

Shenhar, A. J., Dvir, D., Levy, O., \& Maltz, A. C. (2001). Project success: A multidimensional strategic concept. Long Range Planning, 34(6), 699-725. https://doi.org/10.1016/S0024-6301(01)00097-8

Siemiatycki, M. (2016). The making and impacts of a classic text in megaproject management: The case of cost overrun research. International Journal of Project Management, 36(2), 362-371. https://doi.org/10.1016/j.ijproman.2016.07.003

Simon, H. A. (1955). On a class of skew distribution functions. Biometrika, 42(3/4), 425-440. https://doi.org/10.1093/biomet/42.3-4.425

Small, H. (1973). Co-citation in the scientific literature: A new measure of the relationship between two documents. Journal of the American Society for Information Science, 24(4), 265269. https://doi.org/10.1002/asi.4630240406

Smith, D. R. (2007). Ten citation classics from the New Zealand Medical Journal. New Zealand Medical Journal, 120, 2871-2875.

Stack, S. (2012). Citation classics in suicide and life threatening behavior: A research note. Suicide and Life-Threatening Behavior, 42(6), 628-639.

https://doi.org/10.1111/j.1943-278X.2012.00117.x

Turner, J. R., \& Müller, R. (2003). On the nature of the project as a temporary organization. International Journal of Project Management, 21(1), 1-8.

https://doi.org/10.1016/S0263-7863(02)00020-0

van Leeuwen, T., Costas, R., Calero-Medina, C., \& Visser, M. (2013). The role of editorial material in bibliometric research performance assessments. Scientometrics, 95(2), 817-828. https://doi.org/10.1007/s11192-012-0904-5

Waltman, L. (2016). A review of the literature on citation impact indicators. Journal of Informetrics, 10(2), 365-391. https://doi.org/10.1016/j.joi.2016.02.007

Wasserman, S., \& Faust, K. (1994). Social network analysis: Methods and applications. Cambridge University Press. https://doi.org/10.1017/CBO9780511815478

Wing, C. K. (1997). The ranking of construction management journals. Construction Management and Economics, 15(4), 387-398. https://doi.org/10.1080/014461997372953

Woeginger, G. J. (2008). An axiomatic analysis of Egghe's g-index. Journal of Informetrics, 2(4), 364-368.

https://doi.org/10.1016/j.joi.2008.05.002
Wu, H., Xue, X., Zhao, Z., Wang, Z., Shen, G. Q., \& Luo, X. (2020). Major knowledge diffusion paths of megaproject management: A citation-based analysis. Project Management Journal, 51(3), 242-261. https://doi.org/10.1177/8756972819850232

Yin, R. (1994). Case study research: Design and methods. Sage Publishing.

Zadeh, L. (1965). Fuzzy sets. Information and Control, 8(3), 338353. https://doi.org/10.1016/S0019-9958(65)90241-X 